\title{
EFFECT OF ACRA MUTATION IN THE PRESENCE OF STREPTOMYCIN ON GENETIC RECOMBINATION IN ESCHERICHIA COLI
}

\author{
HAKOBU NAKAMURA \\ Biological Institute, Faculty of Science, Konan University \\ Kobe 658
}

Received August 9, 1977

Genetic recombination in Escherichia coli $\mathrm{K} 12$ takes place in the participation of the plasma membrane. This could previously be demonstrated by the experiments using the two membrane genes, $p l s A$ and $\operatorname{acr} A$ (Nakamura et al. 1975). The former gene determines the production of a lipid-synthesizing enzyme (Cronan and Godson 1972), and the latter one determines acriflavine (AF) sensitivity and production of the plasma membrane protein (Nishimukai et al. 1973). The acr $A$ gene furthermore participates in the residing and the replication of plasmids F-gal $+^{+}, \mathrm{R}_{100-1}^{+}$, and $\mathrm{R}_{64-11}^{+}$in the host cells (Nakamura 1974, 1976).

During the course of these investigations we found that streptomycin diminishes the recombination frequency when crosses are made between $\mathrm{Hfr}$ and $\mathrm{F}^{-}$either carrying the $\operatorname{acr} A$ mutation. The present paper will deal with these problems.

\section{MATERIALS AND METHODS}

Bacterial strains. All strains used were derivatives of E. coli K12 (Table 1). Strains $\mathrm{N} 2308$ and N2310 were AF-resistant revertants of the $a c r A$ mutant N43. The former have been demonstrated to carry the second mutation which suppresses the acr $A$ mutation, and the latter to be the back mutant of the acr $A$ mutation (Nakamura 1974). Strains N2503, N2510 and N2512 were AF-sensitive, independently isolated mutants from strain W1895 induced by $\mathrm{N}$-methyl- $\mathrm{N}^{\prime}$-nitro- $\mathrm{N}$-nitrosoguanidine according to the method of Adelberg et al. (1965). All these mutations were mapped in the acr $A$ cistron by the complementation test in which the $\mathrm{F}_{13}$ plasmid carrying mutation acr $A$ was introduced into the $\mathrm{F}^{-}$derivatives which contained their respective $A F$ sensitivity mutations. Strains N2823 and N2824 were spontaneous AF-resistant, independent revertants of strain N2512.

Media. Broth media PGY and L and synthetic medium D were prepared as described by Nakamura (1965), Lennox (1955) and Davis (1950), respectively. No significant difference was found between the growth rates of bacteria in PGY and L. For streptomycin media streptomycin sulfate (Meiji Co., Tokyo) was added to $200 \mu \mathrm{g}$ per ml.

Crosses. Overnight grown cultures of donor and recipient strains were inoculated into $\mathrm{PGY}$ or $\mathrm{L}$ medium and kept shaken at $37^{\circ} \mathrm{C}$ to a density of about $5 \times 10^{8}$ cells per $\mathrm{ml}$. Ten $\mathrm{ml}$ of the recipient culture was mixed with $0.5 \mathrm{ml}$ of the donor culture 
Table 1. List of bacterial strains used*

\begin{tabular}{|c|c|c|c|}
\hline Strain & Sex & Relevant genotype & Source or reference \\
\hline W1895 & $\mathrm{HfrC}$ & met & \\
\hline N43 & $\mathrm{F}^{-}$ & acrA1 lac ara str-r & Nakamura 1965 \\
\hline N90 & $\mathrm{F}^{-}$ & lac ara str-r & Nakamura 1965 \\
\hline $\mathrm{N} 2308$ & $\mathrm{~F}^{-}$ & suppressed acrA1 lac ara str-r & Nakamura 1974 \\
\hline $\mathrm{N} 2310$ & $\mathrm{~F}^{-}$ & lac ara str-r & Nakamura 1974 \\
\hline W3747 & $\mathrm{F}^{\prime}$ & $\mathrm{F}_{13} \mathrm{lac}^{+} / \mathrm{met}$ & \\
\hline $\mathrm{N} 2512$ & $\mathrm{HfrC}$ & acrA10 met & acr $A$ mutant of W1895 \\
\hline $\mathrm{N} 2823$ & $\mathrm{HfrC}$ & Acr-r** met & Acr-r revertant of N2512 \\
\hline $\mathrm{N} 2824$ & $\mathrm{HfrC}$ & Acr-r** met & Acr-r revertant of $\mathrm{N} 2512$ \\
\hline $\mathrm{N} 2503$ & $\mathrm{HfrC}$ & acrA6 met & acr $A$ mutant of $\mathrm{W} 1895$ \\
\hline $\mathrm{N} 2510$ & $\mathrm{HfrC}$ & acr $A 9$ met & acr $A$ mutant of $\mathrm{W} 1895$ \\
\hline
\end{tabular}

* Genetic symbols are as described by Bachmann et al. (1976).

** Phenotype: acriflavine resistance, the genotype being not yet determined.

(i.e., Hfr or $\mathrm{F}^{\prime} 1: \mathrm{F}^{-} 20$ ) in a $500 \mathrm{ml}$ Erlenmyer flask and incubated without shaking in a waterbath at $30^{\circ} \mathrm{C}$ or $37^{\circ} \mathrm{C}$. One tenth $\mathrm{ml}$ of the mating mixture was pipetted into $20 \mathrm{ml}$ of ice cold saline at regular intervals and agitated with a Waring blender to separate mating pairs. One tenth $\mathrm{ml}$ of the samples was plated onto D-lactose $(0.5 \%)$ and D-lactose $(0.5 \%)$ plus streptomycin agar medium. Colonies were counted after $48 \mathrm{~h}$ incubation at $37^{\circ} \mathrm{C}$ or after $72 \mathrm{~h}$ incubation at $30^{\circ} \mathrm{C}$. Genetic constitution of recombinants was analyzed after recombinants were purified by restreaking on the selective agar medium.

Streptomycin uptake by cells. The amount of streptomycin in the cultured media was determined by bioassay. Freshly grown cells were inoculated into PGY medium with an inoculum size of about $1 \times 10^{8}$ cells per ml. Samples withdrawn at intervals were centrifuged at $12,000 \mathrm{rpm}$ for $10 \mathrm{~min}$. The supernatants were subjected to the following bioassay.

Spore suspension of Bacillus subtilis (wild type) and overnight culture of E. coli W1895 were separately spread on PGY agar plates incubated at $42^{\circ} \mathrm{C}$, and thick filter paper disks $(0.8 \mathrm{~mm}$ in diameter $)$ were put on the plates. Samples $(50 \mu \mathrm{l})$ taken from the supernatants of streptomycin cultures prepared as mentioned above were pipetted onto the disks and after overnight incubation at $37^{\circ} \mathrm{C}$, diameter of the inhibitory zone was measured.

\section{RESULTS}

When strain W1895. was mated in the PGY medium with strains N43 and N90 at $30^{\circ} \mathrm{C}$ and $37^{\circ} \mathrm{C}$, kinetics of the appearance of lac $^{+}$met ${ }^{+}$str-r recombinants in the D-lactose plus streptomycin medium was as shown in Fig. 1 . In these crosses, the plates were incubated at $30^{\circ} \mathrm{C}$ for the $30^{\circ}$-mating, and at $37^{\circ} \mathrm{C}$ for the $37^{\circ}$-mating. Fig. 1A shows that, in cross $\mathrm{W} 1895 \times \mathrm{N} 43$ at $30^{\circ} \mathrm{C}$, the first appearance of the recombinant 

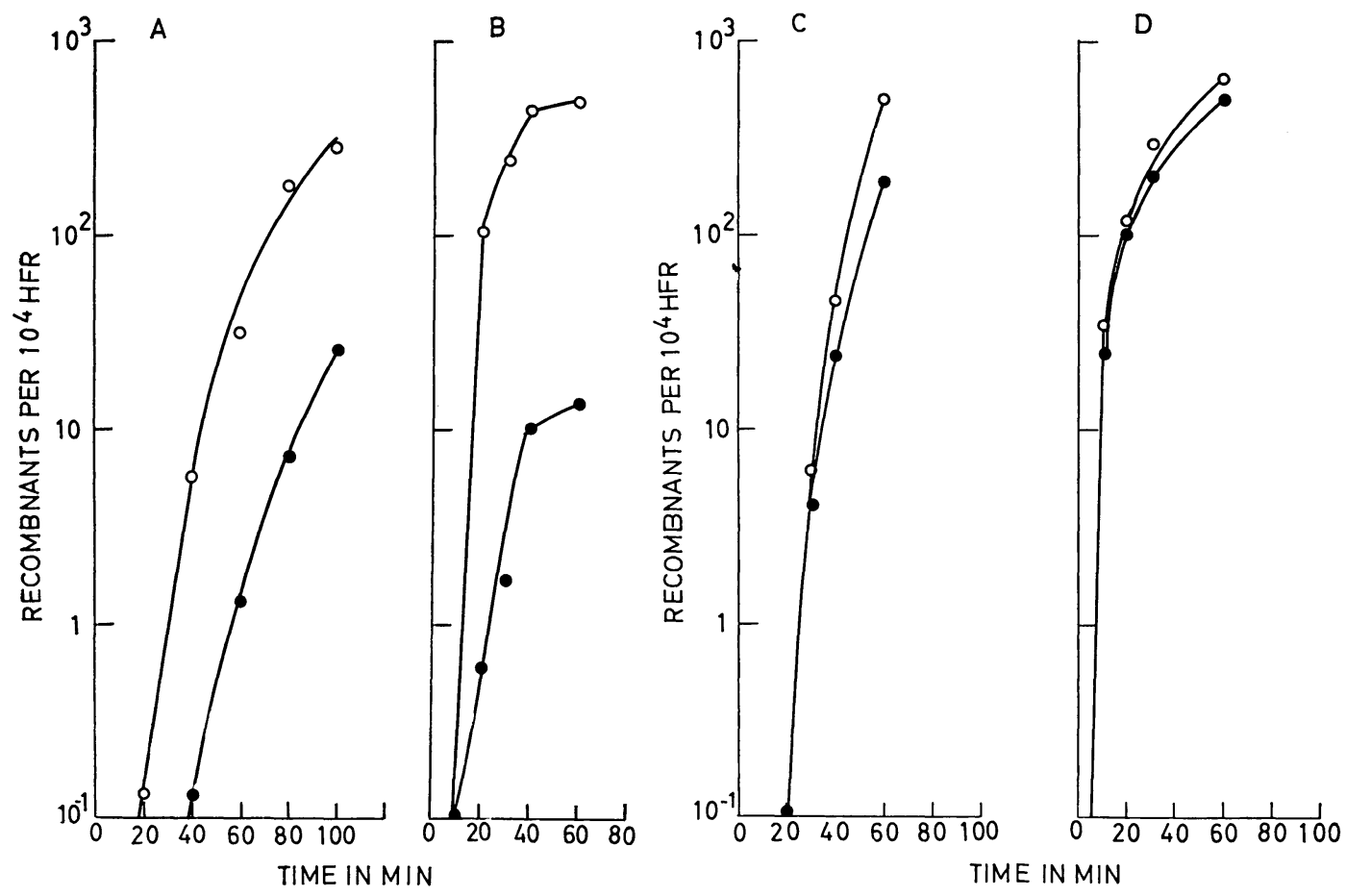

Fig. 1. Kinetics of genetic recombination in the presence (A and $B)$ and absence $(C$ and $D)$ of streptomycin in crosses $\mathrm{W} 1895 \times \mathrm{N} 43(\bullet)$ and $\mathrm{W} 1895 \times \mathrm{N} 90(\mathrm{O})$ at $30^{\circ} \mathrm{C}(\mathrm{A}$ and $\mathrm{C})$ and $37^{\circ} \mathrm{C}(\mathrm{B}$ and $\mathrm{D})$. Mating mixtures $\left(\mathrm{Hfr} 1: \mathrm{F}^{-} 20\right)$ were interrupted and plated at intervals onto D-lactose medium containing $200 \mu \mathrm{g}$ streptomycin per $\mathrm{ml}$.

delays about $25 \mathrm{~min}$ as compared with those in cross $\mathrm{W} 1895 \times \mathrm{N} 90$ at the same temperature. In the $37^{\circ}$-mating, as shown in Fig. 1B, the appearence of the recombinant does not differ in time between the two types of crosses. However, the final yield of the recombinant is 10 -fold less in cross $\mathrm{W} 1895 \times \mathrm{N} 43$ than in cross $\mathrm{W} 1895 \times \mathrm{N} 90$. From these results, it is obvious that the $\operatorname{acr} A$ mutant $\mathrm{N} 43$ is deficient as the genetic recipient.

Next attempt, therefore, is to see whether the deficiency of N43 strain is due to a low frequency of the chromosomal acceptance from the donor during the mating. Donor W1895 and recipients $\mathrm{N} 43$ and $\mathrm{N} 90$ were crossed at $30^{\circ} \mathrm{C}$ with the same manner as above but the interrupted zygotes were plated onto D-lactose agar without addition of streptomycin. The difference in the frequency of recombinant $\left(\mathrm{lac}^{+} \mathrm{met}^{+}\right)$was very small, if any, between the two types of crosses and the first appearance of the recombinant occurred at about $20 \mathrm{~min}$ after the onset of the mating (Fig. 1C). Similar results were obtained also when the mating was performed at $37^{\circ} \mathrm{C}$ (Fig. 1D).

Next, the effect of streptomycin on the recombination was examined for AF-resistant revertant of strain N43, N2308 and N2310. The delayed appearance and the lowered yield of the $\mathrm{lac}^{+} \mathrm{met}^{+}$str-r recombinants on the D-lactose plus streptomycin medium were not observed.

To compare plasmid recipiency between the $\operatorname{acr} A$ and $a c r A^{+}$strains, $\mathrm{F}^{\prime}$ strain W3747 was conjugated with strains $\mathrm{N} 43, \mathrm{~N} 90$, and $\mathrm{N} 2310$ at $30^{\circ} \mathrm{C}$. Diluents of the mating 


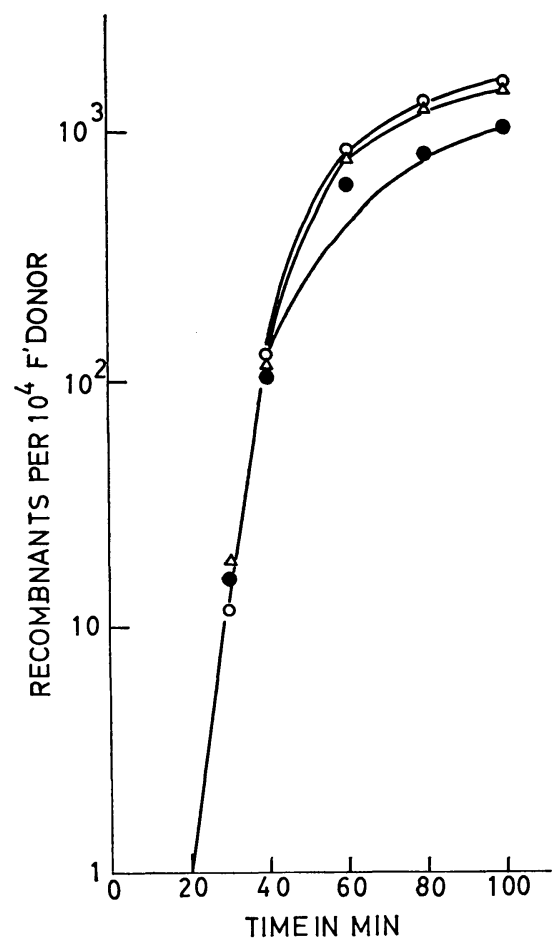

Fig. 2. Kinetics of $\mathrm{F}_{13}$-plasmid transfer in the presence of streptomycin in crosses W $3747 \times \mathrm{N} 43(\bullet)$, $\mathrm{W} 3747 \times \mathrm{N} 90(\mathrm{O})$ and $\mathrm{W} 3747 \times \mathrm{N} 2310(\triangle)$ at $30^{\circ} \mathrm{C}$.

mixtures were plated onto the D-lactose plus streptomycin medium. The yield of $\mathrm{F}_{13}-l_{a c^{+}} /$lac met $^{+}$str-r in cross $\mathrm{W} 3747 \times \mathrm{N} 43$ was slightly lower than in other crosses (Fig. 2).

An experiment, then, was performed to compare transfer frequencies of donor marker str-s to the $a c r A$ and $a c r A^{+}$recipients. The frequencies fell in a range of $0.0-0.4 \%$ of $\mathrm{lac}^{+} \mathrm{met}^{+}$recombinants selected. Thus, it is apparent that the transference of the str-s gene from the donor is not responsible for the lowered recombination in the $\operatorname{acr} A$ recipient.

The recipient strains used in the present experiments were typical streptomycin-resistant $(s t r A)$ mutants. However, we were afraid that $s t r-r$ strains might become partially streptomycin-sensitive when they carry the $\operatorname{acr} A$ allele. To test this possibility, fresh cells of strains N43, N90 and N2310 were plated onto D-glucose $(0.1 \%)$ media containing streptomycin in a series of concentrations (50 to $300 \mu \mathrm{g}$ per $\mathrm{ml}$; no streptomycin in control plates). However, $100 \%$ viability was observed in any of the strains used whether they carried allele $\operatorname{acr} A$ or $a c r A^{+}$. Fresh cells of the three strains were inoculated into liquid D-glucose media containing and not containing $200 \mu \mathrm{g}$ streptomycin per $\mathrm{ml}$ and cultures were shaken at $37^{\circ} \mathrm{C}$. Samples were withdrawn at regular intervals and plated onto PGY agar to count viable cells (Fig. 3). Strikingly, it was observed that streptomycin significantly stimulated the cell division of both $\operatorname{acr} A$ and $\operatorname{acr} A^{+}$strains. However, 


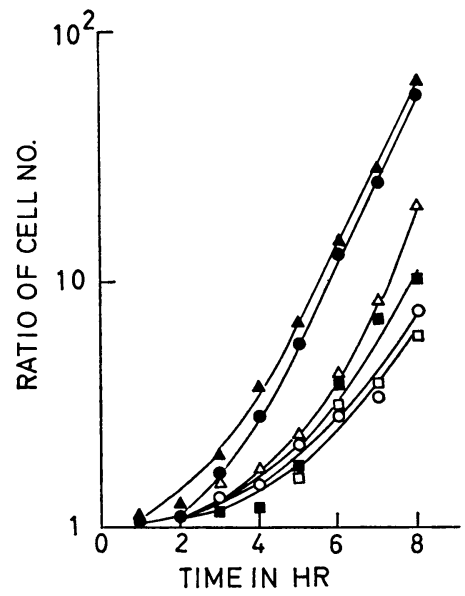

Fig. 3. Cell growth of strains $\mathrm{N} 43(\mathrm{O}, \bullet), \mathrm{N} 90(\triangle, \Delta)$ and $\mathrm{N} 2310(\square, \mathbf{\square})$ in the presence (closed symbols) and absence (open symbols) of streptomycin. PGY-cultured cells were transferred to D-glucose liquid media added and not-added $200 \mu \mathrm{g}$ streptomycin per $\mathrm{ml}$ at zero time. The cultures were shaken at $37^{\circ} \mathrm{C}$.

when these strains were cultured in PGY containing $200 \mu \mathrm{g}$ streptomycin per $\mathrm{ml}$, the drug was inhibitive roughly equally to any of the strains.

Skunary and Reeves (1973) have reported that lethal zygosis occurs during the conjugation of $\mathrm{Hfr}$ and $\mathrm{F}^{-}$cells, when a large excess of donor was mixed. Although our mating system contained donor cells at lower ratio, total female cells were counted during the mating. And conjugation-induced death of the $\operatorname{acr} A$ female cells was not observed.

From the results obtained above, it can be concluded that the lowered frequency of recombination by the presence of streptomycin in cross $\mathrm{W} 1895 \times \mathrm{N} 43$ results from the $\operatorname{acr} A$-mutational effect of the recipient itself. Thus, the following experiments were to see whether the same effect occurred also when the donor strain contained the acrA mutation. For this purpose, several acrA mutants of strain W1895 were isolated as described in Materials and Methods. Fig. 4A shows recombinational kinetics in a cross at $30^{\circ} \mathrm{C}$ using one of them, $\mathrm{N} 2512$, as donor. In these experiments, medium $\mathrm{L}$ was used as the mating medium. In the $\mathrm{N} 2512 \times \mathrm{N} 90$, the rate of $\mathrm{lac}^{+}$met $^{+}$str-r recombinant formation is remarkably low in the presence of streptomycin. However, this recombinational rate was remarkably restored (i) when the streptomycin was not added to the medium (Fig. 4B) and (ii) when AF-resistant revertants of strain N2512, N2823 and N2824, were used as the donor.

Experiments of the same type were conducted with some other acrA mutants of W1895, namely N2503 and N2510. The results were similar as shown in Fig. 4A. Therefore the acrA mutation of the donor also interferes with the recombinational reaction flow in the presence of streptomycin.

The final experiment was to determine and compare streptomycin uptake by the 


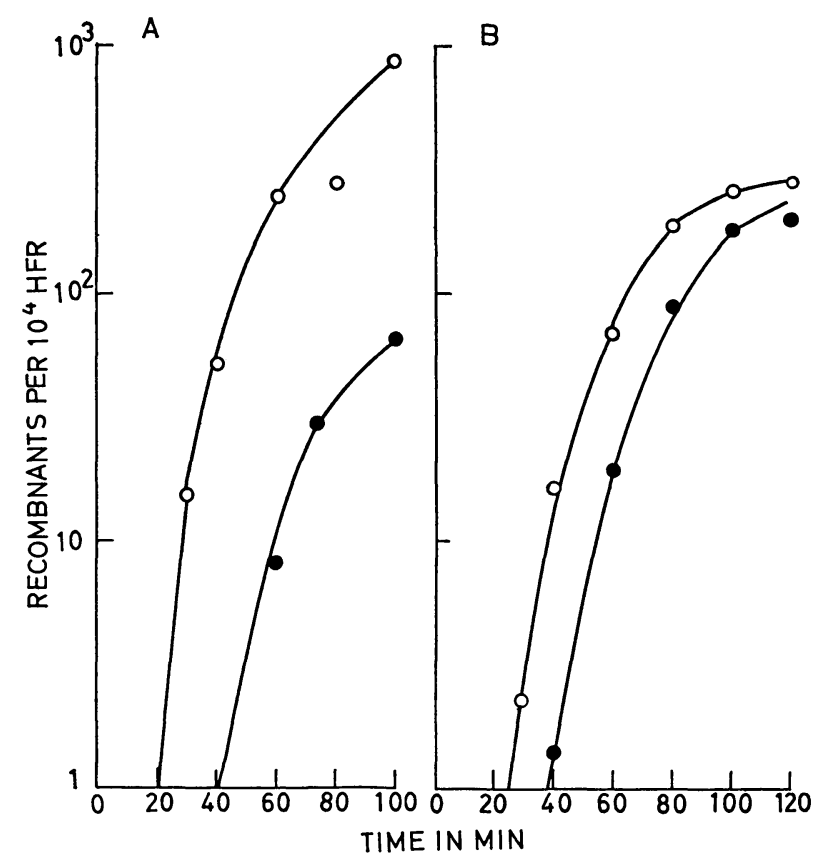

Fig. 4. Kinetics of genetic recombination in the presence $(\mathrm{A})$ and absence (B) of streptomycin in crosses $\mathrm{W} 1895 \times \mathrm{N} 90$ (O) and $\mathrm{N} 2512 \times \mathrm{N} 90$

(•) at $30^{\circ} \mathrm{C}$.

acr $A$ and $a c r A^{+}$cells. Strains N43, N90, N2308 and N2310 were inoculated in the PGY medium containing $200 \mu \mathrm{g}$ streptomycin per $\mathrm{ml}$, and samples were centrifuged at 60,120 , 180 and $240 \mathrm{~min}$ after the inoculation. The supernatant was subjected to bioassay of streptomycin concentration in it. No significant difference in the antibiotic uptake is found between the $\operatorname{acr} A$ and $\operatorname{acr} A^{+}$strains.

\section{DISCUSSION}

Evidence indicates that when either donor or recipient (str-r) contains acrA mutation, the frequency of recombinants is lowered by the presence of streptomycin. On the other hand, the $\operatorname{acr} A$ mutation does not interfere with genetic transfer in the absence (Fig. 1C and D) and presence (Fig. 2) of streptomycin. Therefore, it can be concluded that the $a c r A$ allele hinders the recombination reaction in the presence of the antibiotic.

The $l a c^{+}$gene of the $\mathrm{HfrC}$ strain begins to transfer to the recipient from $8 \mathrm{~min}$ at $37^{\circ} \mathrm{C}$, but from $20 \mathrm{~min}$ at $30^{\circ} \mathrm{C}$, after onset of the mating. The $\operatorname{acr} A$ locus is located about 2 min more proximal than the $l a c^{+}$locus is (Bachmann et al. 1976). Since the recombination inhibition occurs in the presence of streptomycin, the recombinational process in the $\operatorname{acr} A$ zygotes which involves streptomycin-sensitive event(s), is not finished during the mating but after plating onto D-lactose plus streptomycin medium. This suggests that the recombinational reactions proceed more slowly in the acr $A$ zygotes than in the normal zygotes. As assumed from Fig. 1B, for example, more 
than $90 \%$ (based on the normal cross) of the zygotes withdrawn at 60 min after onset of the mating do not accomplish as yet the whole process of recombination.

The mechanism of bactericidal action of the streptomycin has been shown to be of multiplicity. Two important effects among them are an inhibition of protein synthesis (Davis et al. 1974; Schlessinger and Medoff 1975) and impairement of plasma membrane integrity (Anand et al. 1960; Davis et al. 1974; Dubin and Davis 1961; Dubin et al. 1963). The latter effect includes an increase of permeability in the influx and efflux and an inhibition of lipid synthesis. Current studies have clearly demonstrated that the streptomycin-sensitivity, -resistance and -dependence of $E$. coli cells are due to multiple alleles of a single locus, $\operatorname{str} A$, and to a difference in the ribosomal protein (Davis 1964). Therefore, it is apparent that the cellular resistance to streptomycin is determined chiefly by the $\operatorname{str} A$ gene. However, the present results show that the str-r mutant cells still suffer membraneous impairment by streptomycin, which does not lower the viability. Probably, the membraneous impairment will hinder the accomplishment of the genetic recombination.

\section{SUMMARY}

When HfrC strain (str-s) was mated with an acriflavine-sensitive (acr $A$ ) mutant (str-r) recipient in PGY medium and plated onto D-lactose plus streptomycin $(200 \mu \mathrm{g}$ per $\mathrm{ml}$ ) medium, the yield of $l a c^{+}$met $^{+}$str-r recombinant decreased. This effect was more remarkable when the mating and incubation of the plates were done at $30^{\circ} \mathrm{C}$ than $37^{\circ} \mathrm{C}$. However, the recombinant yield was restored to a considerable extent or even completely (i) when the mating mixture was plated onto D-lactose medium (without addition of streptomycin), (ii) when acriflavine-resistant revertants of $\operatorname{acr} A$ mutant were used as the recipients, and (iii) when $\mathrm{F}_{13}$-prime $\left(\mathrm{lac}^{+}-\right.$purE $\left.E^{+}\right)$strain was used as the donor. Under the conditions used, the str-s gene of the donor was transferred only 0.0 to $0.4 \%$ of the $\mathrm{lac}^{+}$gene to the recipients. The streptomycin was not a selective killer to the acrA mutant cell. No lethal zygosis occurred under the present conjugational conditions. From these results, it is concluded that the streptomycin effect on the recombination in the acrA mutant recipient was due to a certain deficiency of the recombinational reaction sequence. However, such streptomycin effect was the case also when donor strains contained the acriflavine-sensitive $(\operatorname{acr} A)$ mutations. And the effect was not observed when acriflavine-resistant revertants of these acr $A$ mutants were used as the donor. Therefore, it is apparent that the $\operatorname{acr} A$ mutation, perhaps a substance produced by its allele, hindered the recombinational reactions. No difference in streptomycin uptake by the cells was found between the $\operatorname{acr} A$ and $\operatorname{acr} A^{+}$strains.

\section{LITERATURE CITED}

Adelberg, E. A., M. Mandel, and G. C. C. Chein, 1965 Optimal conditions for mutagenesis by $\mathrm{N}$-methyl-N'-nitro-N-nitrosoguanidine in Escherichia coli K12. Biochem. Biophys. Res. Comm. 18: 788-795.

Anand. N., B. D. Davis, and A. K. Armitage, 1960 Uptake of streptomycin by Escherichia coli. 
Nature 185: 23-24.

Bachmann, B. J., K. B. Low, and A. L. Taylor, 1976 Recalibrated linkage map of Escherichia coli K12, Bacteriol. Rev. 40: 116-167.

Cronan, J. E., Jr., and G. N. Godson, 1972 Mutants of Escherichia coli with temperature-sensitive lesions in membrane phospholipid synthesis: genetic analysis of glycerol-3-phosphate acyltransferase mutants. Mol. Gen. Genet. 116: 199-210.

Davis, B. D., 1950 Studies on nutritional deficient bacterial mutants isolated by means of penicillin. Experientia 6: 41-50.

Davis, B. D., P. Tai, and B. J. Wallace, 1974 Complex interactions of antibiotics with the ribosome. In "Ribosomes" (M. Nomura, T. Tisseres, and P. Lengyel, ed.) pp. 771-789. Cold Spring Harbor Laboratory.

Davis, J. E., 1964 Studies on the ribosomes of streptomycin-sensitive and resistant strains of Escherichia coli. Proc. Natl. Acad. Sci., U.S.A. 51: 659-664.

Dubin, D. J., and B. D. Davis, 1961 The effect of streptomycin on potassium flux in Escherichia coli. Biochim. Biophys. Acta 52: 400-402.

Dubin, D. J., R. Hancock, and B. D. Davis, 1963 The sequence of some effects of streptomycin in Escherichia coli. Biochim. Biophys. Acta 74: 476-489.

Lennox, E. S., 1955 Transduction of linked genetic characters of the host by bacteriophage Pl. Virology 1: 190-206.

Nakamura, H., T. Tojo, and J. Greenberg, 1975 Interaction of the expression of two membrane genes, $\operatorname{acr} A$ and $p l s A$, in Escherichia coli K12. J. Bacteriol. 122: 874-879.

Nakamura, H., 1974 Plasmid-instability in acrA mutants of Escherichia coli K12. J. Gen. Microbiol. 84: 85-93.

Nakamura, H., $1976 \mathrm{R}$ factor instability in the acriflavine-sensitive mutant of Escherichia coli K12. Japan. J. Genet. 51: 393-395.

Nakamura, H., 1965 Gene-controlled resistance to acriflavine and other basic dyes in Escherichia coli. J. Bacteriol. 90: 8-14.

Nishimukai, H., Y. Arakatsu, A. Suganuma, and H. Nakamura, 1973 Mutation leading to loss of a membrane protein in Escherichia coli K12 (abstract). Japan. J. Genetics 48: 436.

Schlessinger, D., and G. Medoff, 1975 Streptomycin, dihydrostreptomycin and the gentamicins. In "Antibiotics III. Mechanism of Action of Antimicrobial and Antitumor Agents" (J. W. Corcoran, and F. E. Hahn) pp. 535-550. Springer-Verlag Berlin, Heidelberg.

Skunary, R. A., and P. Reeves, 1973 Characterization of lethal zygosis associated with conjugation in Escherichia coli K12. J. Bacteriol. 113: 58-70. 